\title{
PAPILIO PHORCAS.
}

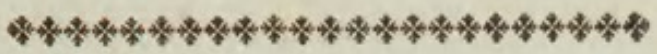

CHARACTER GENERICUS.

Antenna apicem versus crassiores, sæpius clavato-capitatæ.

Ala (sedentis) erectæ sursumque conniventes, (volatu diurno.)

Lin. Syst. Nat. p. 744.

CHARACTER SPECIFICUS, Ëc.

PAPILIO niger, fascia supra viridi subtus pallidiore, alis posterioribus caudatis.

PAPILIO Doreus, P. alis fascia supra viridi, subtus alba.

Lin. Syst. Nat. Gmel. p. 2239. Fab. sp. ins. 2. p. 18.

PAPILIO PHORCAS,

Cram. 1.t. 2. f. в. c.

In Sierra Leona præcipue conspicitur Papilio Phorcas, inter pulchriores merito numerandus. Magnitudinem naturalem ostendit tabula. 



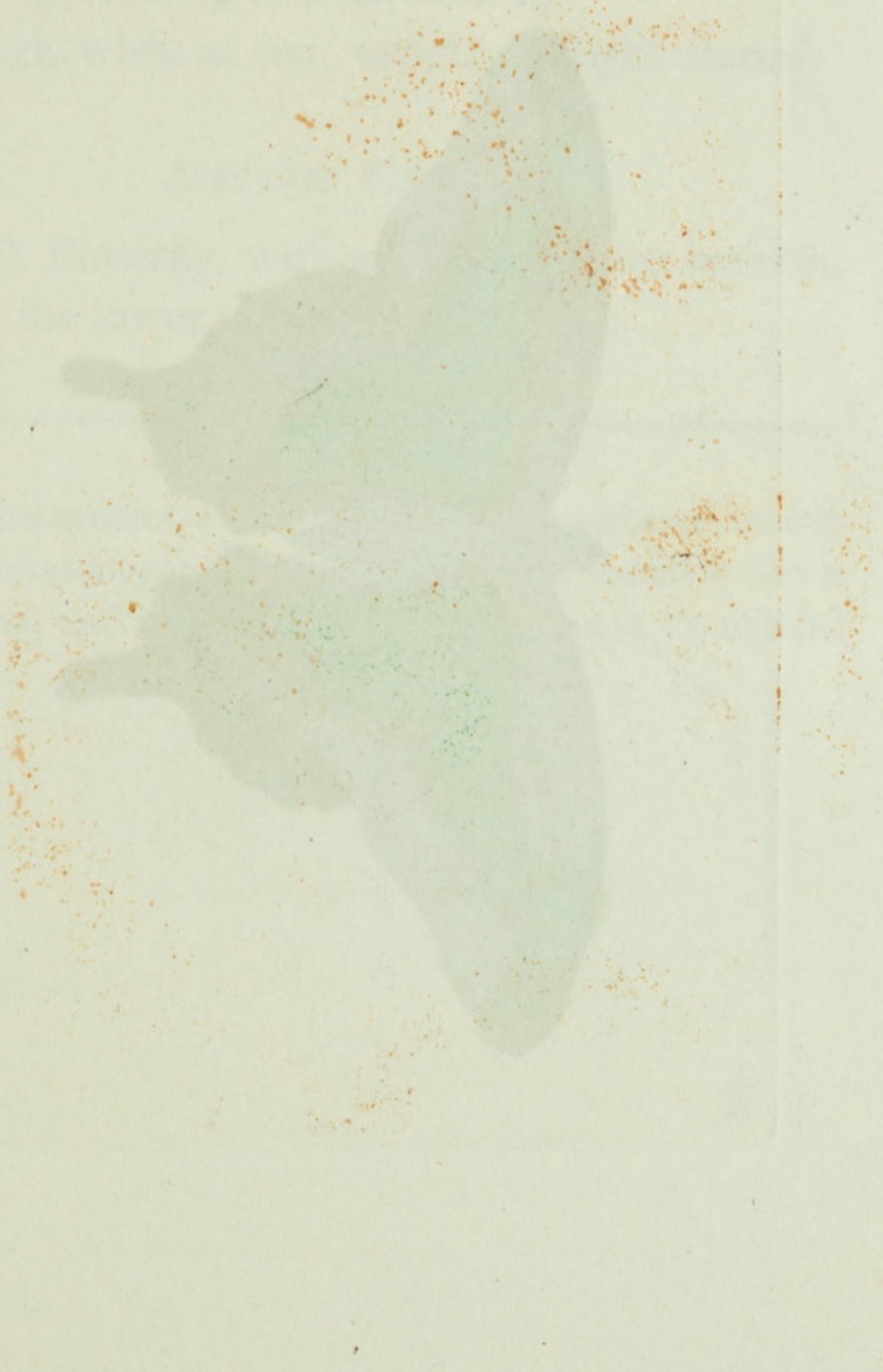




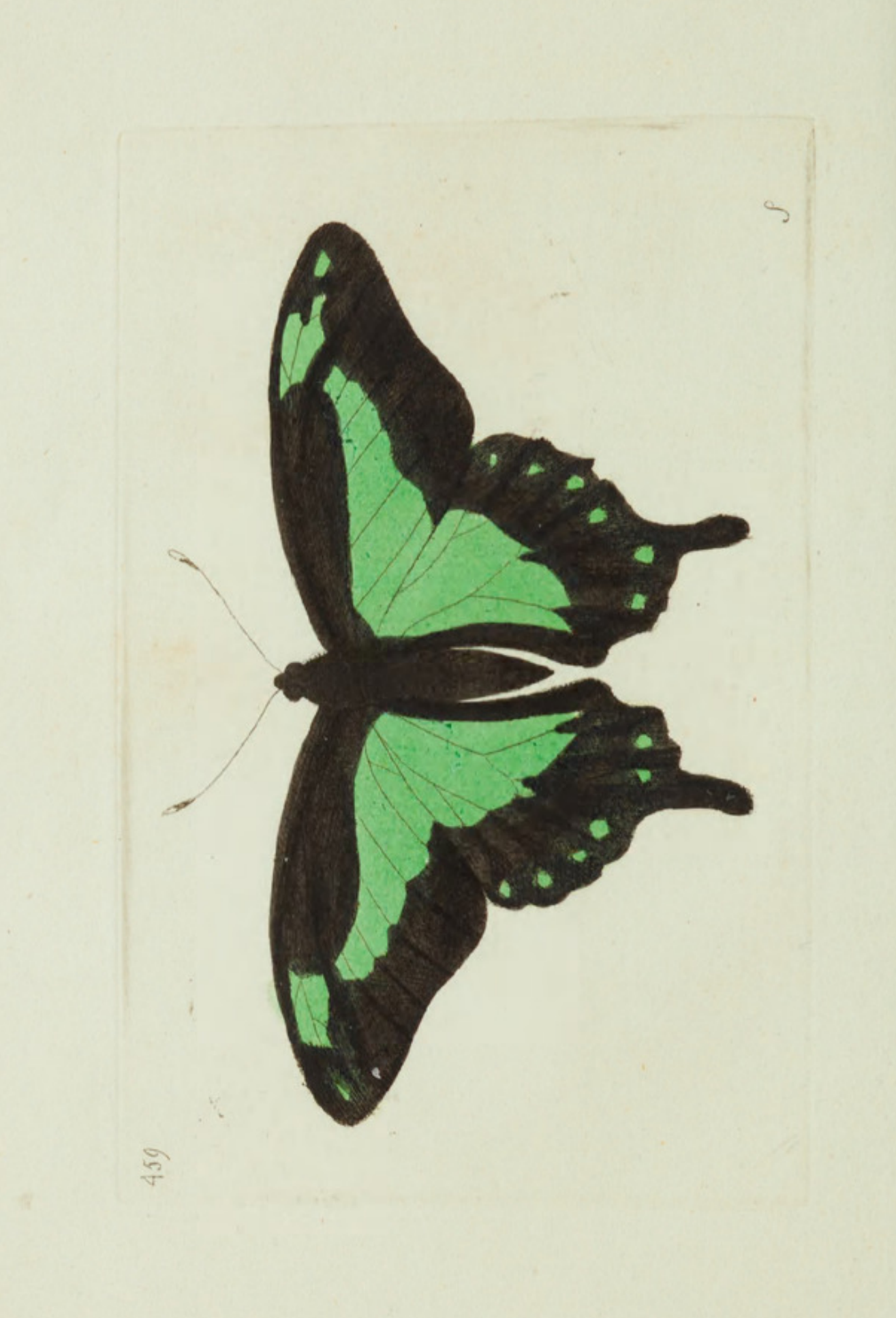




\section{PHORCAS.}

-

\section{GENERIC Character.}

Antennce gradually thickening towards the end, terminating in a clavated tip. Wings, when at rest, upright. Flight diurnal.

\section{SPECIFIC CHARACTER.}

Black Butterfly, with green band, paler beneath, the lower wings tailed.

This species, which may justly be numbered among the most elegant of its tribe, is chiefly found in Sierra Leona, and is represented on the plate in its natural size. 


\section{$2 \mathrm{BHL}$ Biodiversity Heritage Library}

Shaw, George. 1801. "Phorcas, Papilio phorcas [PI. 459]." The Naturalist's Miscellany 12(CXLII), https://doi.org/10.5962/p.310905.

View This Item Online: https://www.biodiversitylibrary.org/item/278722

DOI: https://doi.org/10.5962/p.310905

Permalink: https://www.biodiversitylibrary.org/partpdf/310905

\section{Holding Institution}

Museums Victoria

\section{Sponsored by}

Atlas of Living Australia

\section{Copyright \& Reuse}

Copyright Status: Public domain. The BHL considers that this work is no longer under copyright protection.

This document was created from content at the Biodiversity Heritage Library, the world's largest open access digital library for biodiversity literature and archives. Visit BHL at https://www.biodiversitylibrary.org. 